PRIMANOMICS : JURNAL EKONOMI DAN BISNIS - VOL. 18. No. 3 (2020)

Versi Online Tersedia di : https://jurnal.ubd.ac.id/index.php/ds

| 1412-632X (Cetak) | 2614-6789 (Online) |

\title{
Analysis of Money Circulating in Indonesia during Covid-19 Pandemic
}

\author{
Diana Silaswara1) \\ diana.silaswara@ubd.ac.id \\ Indra Gunawan') \\ indra.gunawan@ubd.ac.id \\ Tjong Se Fung ${ }^{3)}$ \\ tjong.sefung@ubd.ac.id
}

1) 2) 3) Buddhi Dharma University Tangerang, Indonesia, Banten

\begin{abstract}
The purpose of this analysis is to determine the impact of the Covid-19 pandemic on money circulation in Indonesia. Analysis is seen from the side of money circulating in the community based on Bank Indonesia (BI) data, the policies are taken by the government and the impacts that occur in society as a result of the policies.

This research is a descriptive study, because it only observes secondary data obtained from Bank Indonesia since the Covid-19 case began until the end of the study, namely the Bank Indonesia Circulation Money analysis data from December 2019 to April 2020. Then the data is analyzed first combining it with government policy data and data on the impact of Covid-19 on the business world.

The results obtained from the analysis conducted are an increase in the money supply and a decrease in electronic money issued by banks. This is due to a decrease in time deposits (Rupiah and Forex), conditions occur because the effect of the number of companies that are doing Termination Employment and pay for employee severance. Government policies by closing shopping centers, the tourism sector and other policies also contribute to create conditions that make people have to convert their time deposits into savings so that they are easy to use if needed.
\end{abstract}

Keywords: Money Supply, Government Policy, Covid-19 Pandemic 


\section{PRELIMINARY}

Currently around the world is being stricken by a pandemic plague of Covid-19 which has caused millions of people die in less than a year. According to data provided by the site www.worldometers.info and quoted by www.kabar24.bisnis.com mentioned that as of June 21, 2020 at midnight, the number of victims who died as a result of Covid19 totaled 9,035,426 people and it is still growing. With so many fatalities in each country, the whole world has declared that the Covid-19 pandemic is a global disaster, including in Indonesia. The transmission of the virus is very fast and dangerous, this makes the government issued several policies to reduce the activities that allow wider transmission starting from the recommendation of Social Distancing, Large-scale Social Restrictions (PSBB) to the last is to continue to implement the educational process by online until 2021 to suppress the spread.

The existence of these policies automatically affects the economy of the community. This can be seen from the Money Circulation Analysis released by BI for November 2019 to April 2020 (see Figure 1). In this analysis the data used are currency (cash), electronic money (e-money either applications or chips), time deposits (deposits) and savings.

Figure 1. Analysis of Money Circulating in Indonesia

\begin{tabular}{|c|l|c|c|c|c|}
\hline No & Month & Banknotes & $\begin{array}{c}\text { Electronic } \\
\text { Money }\end{array}$ & $\begin{array}{c}\text { Time Deposits } \\
\text { (Rp and Forex) }\end{array}$ & $\begin{array}{c}\text { Savings } \\
\text { (Rp and Forex) }\end{array}$ \\
\hline 1 & Nov 2019 & $622.4 \mathrm{~T}$ & $2.6 \mathrm{~T}$ & $2.398,3 \mathrm{~T}$ & $1.803,3 \mathrm{~T}$ \\
\hline 2 & Des 2019 & $654.7 \mathrm{~T}$ & $2.7 \mathrm{~T}$ & $2.353,4 \mathrm{~T}$ & $1.877,7 \mathrm{~T}$ \\
\hline 3 & Jan 2020 & $616.1 \mathrm{~T}$ & $2.3 \mathrm{~T}$ & $2.395,8 \mathrm{~T}$ & $1.831,4 \mathrm{~T}$ \\
\hline 4 & Feb 2020 & $608 \mathrm{~T}$ & $2.3 \mathrm{~T}$ & $2.445,9 \mathrm{~T}$ & $1.829,8 \mathrm{~T}$ \\
\hline 5 & $\begin{array}{l}\text { Maret } \\
2020\end{array}$ & $620.4 \mathrm{~T}$ & $2.3 \mathrm{~T}$ & $2.464,6 \mathrm{~T}$ & $1.900 \mathrm{~T}$ \\
\hline 6 & April 2020 & $634.1 \mathrm{~T}$ & $2.2 \mathrm{~T}$ & $2.422,7 \mathrm{~T}$ & $1.870,6 \mathrm{~T}$ \\
\hline
\end{tabular}

Source: Bank Indonesia 
PRIMANOMICS : JURNAL EKONOMI DAN BISNIS - VOL. 18. NO. 3 (2020)

Versi Online Tersedia di : https://jurnal.ubd.ac.id/index.php/ds

| 1412-632X (Cetak) | 2614-6789 (Online) |

The conclusions that can be drawn from Table 1 above include:

1. Currency in circulation, electronic money and savings increased in December 2019 due to year-end THR giving bonuses and bonuses for employees.

2. Currency circulating has decreased until February and has again increased in March and April 2020.

3. Electronic Money issued by the Bank run into significantly decrease in January amounted to 4 Trillion Rupiah and then tends to be stable until March and again decreased by 1 Trillion Rupiah in April 2020.

4. Time Deposits increased up to March and decreased significantly by IDR 41.9 trillion in April 2020.

5. Savings decreased until last February run into a significant increase of 70.2 Trillion Rupiah in March 2020, and decreased again in April 2020.

Based on data of the increase and decrease that occurred in the analysis of money supply issued by BI, the authors intend to make research on this matter by linking it with policies taken by the government and the impact of Covid-19 that occurred in the business world. The time of the analysis is adjusted to the time of the BI Money Circulation Analysis data, from December 2019 to April 2020.

\section{RESULTS AND DISCUSSION}

This study uses secondary data, starting with President Jokowi's announcement regarding nine policies amid the Covid-19 Pandemic as quoted by www.kompas.com. The nine economic policies include:

1. Instruct all Ministers and Regional Heads to cut spending plans that are not priority expenditures in the National Budget (APBN) and Regional Budget (APBD).

2. Issued Presidential Instruction No. 4 of 2020 concerning Re-focusing of activities, ReAllocation of Budget and Procurement of Goods and Services in the Context of Accelerating Handling of Corona Virus Disease 2019 
3. Requesting the Central Government and Local Governments to guarantee the availability of basic commodities, followed by ensuring the maintenance of the purchasing power of the people, especially the grassroots.

4. Request that the Cash Forced Intensive Program be reproduced with a note that it must be followed by compliance with the Corona Virus prevention protocol.

5. Mention that the government is giving an additional Rp.50.000 (to Rp.200.000) for six months to the holders of Cheap Basic Food Cards.

6. Speed up the implementation of the Pre-Work Card to anticipate workers who are laid off, workers lose their income and micro entrepreneurs who lose their markets and turnover.

7. The government pays income tax (PPh) 21, which has been paid by taxpayers (WP) for employees in the processing industry.

8. The Financial Services Authority (OJK) provides a decrease in interest and postponement of installments for a year, from banks and the non-bank financial industry (Micro and Medium Enterprises (MSMEs) under 10 billion Rupiah).

9. Low-income people who do subsidized housing loans (KPR) will be given stimulus. In addition to the policies stated above, the author also made observations regarding other policies issued both by the Ministry agencies in the Central Government and the Government Regions related to community activities during March - May 2020 in Indonesia (can be seen in figure 2).

Figure 2.Policies carried out during March - May 2020

\begin{tabular}{|c|c|c|c|l|}
\hline No & Month & Date & Activity & \multicolumn{1}{|c|}{ Implementation (Sumber) } \\
\hline \multirow{2}{*}{2} & & 15 & $\begin{array}{c}\text { Maintaining } \\
\text { Social } \\
\text { Distances }\end{array}$ & $\begin{array}{l}\text { Do not allow converge, and the Ministry of } \\
\text { SOEs instructs employees aged 50 years and } \\
\text { over to work from home (www.msn.com) }\end{array}$ \\
\cline { 3 - 5 } & \multirow{2}{*}{3} & 15 & Mall closure & $\begin{array}{l}\text { The closure of the Mall by the local } \\
\text { government following the Social Distancing } \\
\text { and Large-Scale Social Limitation policy was } \\
\text { imposed (Berbagai sumber (situs msn, } \\
\text { liputan6 dan republika)) }\end{array}$ \\
\cline { 3 - 5 } & 19 & $\begin{array}{c}\text { Prohibition } \\
\text { of } \\
\text { International } \\
\text { Flights }\end{array}$ & $\begin{array}{l}\text { Ministry of Transportation: No Closing of } \\
\text { International Flights Except from and to } \\
\text { China (www.kompas.com })\end{array}$ \\
\hline
\end{tabular}


PRIMANOMICS : JURNAL EKONOMI DAN BISNIS - VOL. 18. No. 3 (2020)

Versi Online Tersedia di : https://jurnal.ubd.ac.id/index.php/ds

| 1412-632X (Cetak) | 2614-6789 (Online) |

\begin{tabular}{|c|c|c|c|c|}
\hline 4 & & 21 & train & $\begin{array}{l}\text { Some trips were canceled and the Electric } \\
\text { Train was reduced in number (from } 74 \text { to 54) } \\
\text { and only opened at 6:00 to 20:00 } \\
\text { (www.liputan6.com ) }\end{array}$ \\
\hline 5 & & 24 & $\begin{array}{l}\text { Bank } \\
\text { Operational } \\
\text { Hours }\end{array}$ & $\begin{array}{l}\text { The operational hours of the Bank were } \\
\text { shortened from } 18: 30 \text { to } 17: 00 \text {, and service } \\
\text { times from } 08-15 \text { to } 09-15 \\
\text { (www.finansial.bisnis.com) }\end{array}$ \\
\hline 6 & & 27 & $\begin{array}{c}\text { Regional } \\
\text { Quarantine }\end{array}$ & $\begin{array}{l}\text { Quarantine is carried out per region at the } \\
\text { discretion of the local government and not yet } \\
\text { officially from the central government } \\
\text { (www.kompas.com) }\end{array}$ \\
\hline 7 & \multirow{8}{*}{ April } & 1 & Train & $\begin{array}{l}\text { The Electric Train was reduced again to } 26 \\
\text { trips (www.id.wikipedia.org) }\end{array}$ \\
\hline 8 & & 10 & $\begin{array}{l}\text { Motorcycle } \\
\text { Service has } \\
\text { disappeared }\end{array}$ & $\begin{array}{l}\text { Motorcycle taxi services on the Gojek and } \\
\text { Grab application are removed, so that online } \\
\text { motorbikes can only serve other service } \\
\text { orders (www.msn.com ) }\end{array}$ \\
\hline 9 & & 10 & $\begin{array}{l}\text { Large-scale } \\
\quad \text { Social } \\
\text { Restrictions } \\
\quad \text { (PSBB) }\end{array}$ & $\begin{array}{l}\text { The existence of motor regulations can only } \\
\text { be used alone or with family members, the } \\
\text { contents of the car must be } 50 \% \text { of the } \\
\text { passenger capacity of the car, and must use } \\
\text { the Covid- } 19 \text { safety standard. PSBB rules are } \\
\text { listed in Minister of Health Regulation No. } 9 \\
\text { of } 2020 \text { and begin in several major cities in } \\
\text { Indonesia. ( } \underline{\text { www.kompas.com }} \text { ) }\end{array}$ \\
\hline 10 & & 14 & $\begin{array}{l}\text { National } \\
\text { Disaster }\end{array}$ & 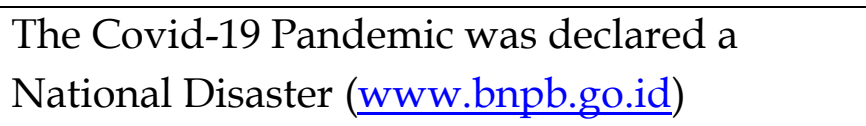 \\
\hline 11 & & 21 & $\begin{array}{l}\text { Prohibition } \\
\text { on returning } \\
\text { to one's } \\
\text { home area }\end{array}$ & $\begin{array}{l}\text { The government prohibits going home for all } \\
\text { residents in the red zone (www.liputan6.com })\end{array}$ \\
\hline 12 & & 23 & $\begin{array}{c}\text { Flight } \\
\text { Prohibition }\end{array}$ & $\begin{array}{l}\text { Indonesia Stop International and Domestic } \\
\text { Flights } 24 \text { April - } 1 \text { June (www.suara.com) }\end{array}$ \\
\hline 13 & & 25 & Train & $\begin{array}{l}\text { All long and medium distance train trips are } \\
\text { canceled (www.id.wikipedia.org) }\end{array}$ \\
\hline 14 & & 25 & $\begin{array}{c}\text { Domestic } \\
\text { Flight } \\
\text { Prohibition }\end{array}$ & $\begin{array}{l}\text { Airlines are forbidden to transport domestic } \\
\text { passengers, but international flights are still } \\
\text { permitted ( } \underline{w w w . l i p u t a n 6 . c o m})\end{array}$ \\
\hline
\end{tabular}




\begin{tabular}{|c|c|c|c|c|}
15 & Mei & $\begin{array}{c}\text { Prohibition } \\
\text { on returning } \\
\text { to one's } \\
\text { home area }\end{array}$ & $\begin{array}{l}\text { In order to prevent Covid from spreading to } \\
\text { various regions, returning home is prohibited } \\
\text { and every road flow is guarded by the } \\
\text { authorities. (www.liputan6.com) }\end{array}$ \\
\hline
\end{tabular}

Source: Observation Results

Many policies implemented by the government to prevent the spread of Covid-19 have an impact on people's lives, The many policies made by the government to prevent the spread of Covid-19 have an impact on people's lives, because the people who work eventually cannot work normally and obtain optimal income. One of them is the mall closure policy, many tenants suffer losses and ultimately affect all employees who work there. Following are the results of operations regarding the impact of Covid-19 on the community's economy.

Figure3. The Impact of the Covid-19 Pandemic on the Business World

\begin{tabular}{|c|c|c|c|}
\hline No & Month & Date & Information (Sources) \\
\hline 1 & Jan & Early & $\begin{array}{l}\text { Lippo Karawaci Termination of employment K } 676 \\
\text { employees and laid off } 73 \text { employees (www.idntimes.com) }\end{array}$ \\
\hline 2 & Jan & -- & $\begin{array}{l}\text { Real sales issued by Bank Indonesia already showed a } \\
\text { contraction of } 0.3 \% \text { in January } 2020 \text { and BPS recorded the } \\
\text { number of foreign tourist arrivals down } 7.62 \% \text { in January } \\
2020 \text {. (www.detikFinance.com) }\end{array}$ \\
\hline 3 & Feb & -- & $\begin{array}{l}\text { Car sales in January and February also dropped } 2.4 \% \\
\text { (yoy). Indications of a decline in private consumption are } \\
\text { also shown by the drop in domestic and foreign travel } \\
\text { (www.detikFinance.com) }\end{array}$ \\
\hline 2 & Maret & 28 & $\begin{array}{l}\text { PT Ramayana Lestari Sentosa Tbk (Ramayanan Store) has } \\
\text { closed } 16 \text { stores (www.detikFinance.com) }\end{array}$ \\
\hline 3 & \multirow{4}{*}{ April } & 6 & $\begin{array}{l}\text { 1,266 hotels closed and 150,000 employees laid off (data } \\
\text { from the Indonesian Hotel and Restaurant Association } \\
\text { (PHRI)) (www.katadata.co.id) }\end{array}$ \\
\hline 4 & & \multirow{2}{*}{18} & $\begin{array}{l}\text { GoPro terminates employment relationships with } 200 \\
\text { employees (www.Kompas.com) }\end{array}$ \\
\hline 5 & & & $\begin{array}{l}\text { Garuda Indonesia employee salary deduction } \\
\text { (www.detikFinance.com) }\end{array}$ \\
\hline 6 & & 28 & $\begin{array}{l}\text { KFC closed } 97 \text { outlets, implemented a work scheduling } \\
\text { policy and laid off some workers with the provisions of } \\
\text { wage deductions and postponement of wage payments } \\
\text { and adjustment of holiday allowance payments } \\
\text { (wWw.detikFinance.com) }\end{array}$ \\
\hline
\end{tabular}


PRIMANOMICS : JURNAL EKONOMI DAN BISNIS - VoL. 18. No. 3 (2020)

Versi Online Tersedia di : https://jurnal.ubd.ac.id/index.php/ds

| 1412-632X (Cetak) | 2614-6789 (Online) |

\begin{tabular}{|c|c|c|c|}
\hline 7 & \multirow{4}{*}{ Mei } & 7 & $\begin{array}{l}\text { Airbnb Termination of Employment 1,900 employees } \\
\text { (www.Kompas.com) }\end{array}$ \\
\hline 8 & & 21 & $\begin{array}{l}\text { Deduction of salary for all Lion Air Group employees, and } \\
\text { postponement of holiday allowance especially for pilots, } \\
\text { structural officials, mechanics, cabin crew, including flight } \\
\text { attendants and staff (www.idntimes.com) }\end{array}$ \\
\hline 9 & & 23 & $\begin{array}{l}310 \text { reports entered into the PPNI Legal Aid Agency } \\
\text { Secretary regarding complaints of salary deductions and } \\
\text { holiday allowances (www.Republika.co.id) }\end{array}$ \\
\hline 10 & & 28 & $\begin{array}{l}\text { Air Asia has } 873 \text { employees laid off and } 9 \text { employees are } \\
\text { cut off (data as of Dec 2019, number of employees is 1,691) } \\
\text { (www.Kompas.com) }\end{array}$ \\
\hline 11 & \multirow{4}{*}{ June } & 6 & $\begin{array}{l}7 \text { Indocement factories at Citereup closed and Directors' } \\
\text { salaries reduced (www.Liputan6.com) }\end{array}$ \\
\hline 12 & & 8 & $\begin{array}{l}\text { PT. Matahari Department Store Tbk or Matahari Store cut } \\
\text { the salary of } 12,080 \text { employees and laid off } 5,623 \\
\text { employees (www.idntimes.com) }\end{array}$ \\
\hline 13 & & 16 & $\begin{array}{l}\text { Grab confirms the Termination of Employment of } 360 \\
\text { employees (www.Kompas.com) }\end{array}$ \\
\hline 14 & & 22 & $\begin{array}{l}\text { Since early } 2020 \text { KFC has laid off 4,988 employees, cut } \\
\text { salaries to } 4,847 \text { employees and closed } 115 \text { outlets } \\
\text { throughout Indonesia (wWw.idntimes.com) }\end{array}$ \\
\hline
\end{tabular}

Source: Observation Results

\section{CONCLUSION}

Quoting from the site www.kompas.com, it is known that the Covid-19 virus was only reported in the Wuhan area of China to WHO on December 31, 2019, and only entered Indonesia on March 02, 2020 (Quoting from the site www.id.wikipedia.org). But even though it only entered Indonesia in March 2020, the economic downturn has occurred since January and February 2020. By reading the available data from the three sources above, several conclusions can be drawn for each month, including:

1. In December 2019

a) In this month, there hasn't been too much change in the money in circulation, and the public is still enthusiastic about the issue of moving the State Capital to Kalimantan.

b) There is still an increase in the money supply and savings because in December many people get Christmas Day Benefits and year-end bonuses. 
2. In January 2020

a) In January there has been a decline in the area of currency circulating and electronic money due to the large number of tourism sectors that have begun to close, resulting in a decline in tourists. The start of lethargy in the field of tourism and sales made people finally use existing savings to meet their needs. This resulted in savings run into a significant decline in January 2020 when compared with the previous month's data.

b) While in some industrial sectors it has experienced an increase with the news about Covid-19, for example companies that produce medical devices, so that there are additions in term deposits.

3. In February 2020

a) The decline in the use of money in circulation is still happening this month, this is due to private consumption which accounts for nearly $60 \%$ of national economic movements, both. retail sales (traditional markets and modern markets) have decreased

b) Reductions on the savings side are more used as tactical funds in case they are needed.

4. In March 2020

a) Because the Covid-19 case was only discovered in Indonesia in early March 2020, many events and policies have been carried out this month to prevent more widespread transmission.

b) Currency in circulation and savings have increased, one of the reasons is because in March many members of the community experienced layoffs and get severance pay. And they save the money back in the bank, either in the form of savings or in the form of term deposits.

c) Prohibition of Shopping Centers to operate is also one of the causes of the rise in layoffs that occur in the retail sector.

5. In April 2020

a) In April there were still many policies lying off employees, salary cuts and termination of employment which resulted in increased use of currency. 
PRIMANOMICS : JURNAL EKONOMI DAN BISNIS - VOL. 18. No. 3 (2020)

Versi Online Tersedia di : https://jurnal.ubd.ac.id/index.php/ds

| 1412-632X (Cetak) | 2614-6789 (Online) |

b) With the lack of income that is usually done by the public is to use savings and disburse time deposits to meet their needs while in Covid-19 conditions are still ongoing.

6. BI's financial analysis data on November 2019 was not discussed further because it was only used as a comparison material to find out the changes that occurred in December 2019, according to the announcement of the Covid-19 virus in Wuhan, China.

7. The data on May and June 2020 are not discussed, because the BI Money Circulation data as one of the comparison materials is only available until April 2020. So the observational data for May and June 2020 only serve as supplementary data.

\section{REFERENCE}

https://kabar24.bisnis.com/read/20200622/19/1255744/update-covid-19-global-

9.035.426-kasus-di-seluruh-dunia-50-persen-sembuh (Accessed June 23, 2020 on10:28)

https:// www.bi.go.id/id/publikasi/perkembangan/Pages/M2-November-2019.aspx

(Accessed 24 June 24, 2020 on 21:09)

https://www.bi.go.id/id/publikasi/perkembangan/Pages/M2-Desember-2019.aspx

(Accessed 19/06/2020 on 15:00)

https://www.bi.go.id/id/publikasi/perkembangan/Pages/M2-Januari-2020.aspx

(Accessed 19/06/2020 on 15:14)

https://www.bi.go.id/id/publikasi/perkembangan/Pages/M2-Februari-2020.aspx

(Accessed 19/06/2020 on 19:10)

https:// www.bi.go.id/id/publikasi/perkembangan/Pages/M2-Maret-2020.aspx

(Accessed 19/06/2020 on19:35)

https:// www.bi.go.id/id/publikasi/perkembangan/Pages/M2-April-2020.aspx

(Accessed 19/06/2020 on19:43)

https://www.msn.com/id-id/berita/teknologidansains/hari-ini-layanan-ojek-motor-

menghilang-dari-aplikasi-gojek-dan-grab/ar-BB12pe7k (Accessed June 222020

on19:34)

https:/ / www.kompas.com/tren/read/2020/04/20/175146965/ini-daftar-20-wilayah-

di-indonesia-yang-tetapkan-psbb (Accessed June 22, 2020 on19:39)

https://bnpb.go.id/berita/presiden-tetapkan-covid19-sebagai-bencana-nasional

(Accessed June 22, 2020 on20:44)

https:/ / www.liputan6.com/news/read/4257400/4-pernyataan-jokowi-soal-ramadandan-larangan-mudik (Accessed June 22, 2020 on20:46) 
https://www.kompas.com/tren/read/2020/03/30/105141365/update-5-wilayah-diindonesia-yang-berlakukan-karantina-terbatas-hingga?page=all\#page2 (Accessed June 22, 2020 on20:51)

https://finansial.bisnis.com/read/20200324/90/1217502/cegah-corona-meluas-biakan-batasi-jam-operasional-bank (Accessed June 22, 2020 on 21:02)

https:/ / www.liputan6.com/news/read/4229555/ridwan-kamil-krl-commuter-linesetop-operasi-sementara-18-april (Accessed June22, 2020 on 21:07)

https://www.liputan6.com/news/read/4208782/jam-operasional-commuter-linedibatasi-penumpang-berdesakan (Accessed June22, on21:08)

https://www.liputan6.com/news/read/4208372/who-ubah-penerapan-socialdistancing-menjadi-physical-distancing (Accessed June 22, 2020 on21:11)

https://www.msn.com/id-id/gayahidup/hidup-pintar/social-distancing-efektifcegah-penyebaran-corona-bagaimana-caranya/ar-BB11f0Oe (Accessed June 22, 2020 on $21: 16)$

https:/ / travel.kompas.com/read/2020/03/20/053300927/kemenhub-tidak-adapenutupan-penerbangan-internasional-kecuali-dari-dan-ke (Accessed June 22, 2020 on $21: 22)$

https://www.msn.com/id-id/ekonomi/ekonomidanbisnis/fakta-terbaru-penutupandan-pembukaan-kembali-pusat-perbelanjaan-di-jakarta/ar-BB14AckT (Accessed June 23, 2020 on14:59)

https:// www.liputan6.com/ramadan/read/4259591/memancing-kerumunan-maldan-belasan-pusat-perbelanjaan-di-mataram-ditutup (Accessed June 23, 2020 on15:00)

https://republika.co.id/berita/qamg0m335/tiga-mal-dan-belasan-pusat-perbelanjaandi-mataram-ditutup (Accessed June 23, 2020 on15:01)

https://www.suara.com/news/2020/04/23/201610/indonesia-stop-penerbanganinternasional-dan-domestik-24-mei-1-juni (Accessed June 22, 2020 on21:25)

https://www.liputan6.com/bisnis/read/4237098/maskapai-dilarang-angkutpenumpang-domestik-tapi-internasional-boleh (Accessed June 22, 2020 on21:38) https://jateng.kemenag.go.id/warta/informasi/detail/surat-edaran-nomor-se15tahun-2020-tentang-panduan-penyelenggaraan-kegiatan-keagamaa (Accessed June 22, 2020 on21:53)

https://nasional.kompas.com/read/2020/03/26/07412441/9-kebijakan-ekonomijokowi-di-tengah-pandemi-covid-19-penangguhan-cicilan?page=all\#page2 (Accessed June 22, 2020 on22:00)

https:/ / finance.detik.com/ berita-ekonomi-bisnis/d-4957376/begini-virus-coronalumpuhkan-ekonomi-ri (Accessed June 242020 on20:10) https://www.msn.com/id-id/news/nasional/tenaga-medis-alami-pemotongan-gajidan-thr-di-tengah-pandemi/ar-BB14umzY (Accessed June 21, 2020 on 19:21) 
PRIMANOMICS : JURNAL EKONOMI DAN BISNIS - VOL. 18. No. 3 (2020)

Versi Online Tersedia di : https://jurnal.ubd.ac.id/index.php/ds

| 1412-632X (Cetak) | 2614-6789 (Online) |

https:// www.msn.com/id-id/berita/teknologidansains/grab-mem-phk-360-

karyawan-termasuk-di-indonesia/ar-BB15yntw (Accessed June 21, 2020 on19:23)

https:/ / tekno.kompas.com/read/2020/05/07/10180087/pesanan-kamar-banyak-

dibatalkan-airbnb-phk-1.900-karyawan (Accessed June 21, 2020 on19:37)

https://tekno.kompas.com/read/2020/04/18/15030067/gopro-mem-phk-200-

karyawan-model-bisnis-berubah (Accessed June 21, 2020 on 19:45)

https:/ / finance.detik.com/berita-ekonomi-bisnis/d-4981566/gaji-karyawan-garudaindonesia-dipotong-ini-rinciannya (Accessed June 21, 2020 on19:51)

https://www.kompasiana.com/adlierafqie/5e7a0b2e53807b48957b0503/pandemikcovid-19-dan-dampaknya-bagi-depresi-ekonomi-indonesia

https://katadata.co.id/berita/2020/05/26/phk-dan-efisiensi-karyawan-melandaperusahaan-publik-ini-daftarnya (Accessed June 21, 2020 on 20:21)

https://finance.detik.com/berita-ekonomi-bisnis/d-5000156/puluhan-gerainya-tutupgaji-dan-thr-karyawan-kfc-ditunda (Accessed June 21, 2020 on 20:55)

https://today.line.me/id/pc/article/Imbas+Corona+7+Pabrik+Indocement+Tak+Ber operasi+dan+Gaji+Direlsi+Dipangkas-V9p6O1 (Accessed June 21, 2020 on 20:57)

https:/ / bali.idntimes.com/business/economy/auriga-agustina-3/duh-mataharirumahkan-5623-karyawan-dan-potong-gaji-hingga-50-persen-regional-bali

(Accessed June 21, 2020 on 21:02)

: https://www.idntimes.com/business/economy/auriga-agustina-3/4-perusahaanbesar-terkemuka-ini-phk-karyawannya-akibat-virus-corona (Accessed June 21, 2020 on 21:05)

https:/ / www.liputan6.com/bisnis/read/4260504/pandemi-corona-bikin-kfc-tutup115-gerai-dan-rumahkan-4988-karyawan (Accessed June 21, 2020 on 21:11)

https://finance.detik.com/berita-ekonomi-bisnis/d-4962608/pengusaha-potong-gajikaryawan-di-tengah-corona-ini-kata-

kemnaker?_ga=2.247165060.1659937503.1592741855-2006888850.1572152777

(Accessed June 21, 2020 on 21:14)

https://money.kompas.com/read/2020/05/28/134000226/pendapatan-jeblok-airasiaindonesia-rumahkan-873-karyawan?.ga=2.261196237.1305213769.15926258161637910212.1572152743 (Accessed 21:17)

https:/ /idnews.co.id/lion-air-potong-gaji-dan-tunda-pembayaran-thr-seluruh-

karyawan/ (Accessed June21, 2020 on 21:25)

https:/ / finance.detik.com/bursa-dan-valas/d-3941670/tutup-16-toko-ramayana-

hemat-biaya-rp-29-miliar (Accessed June 22, 2020 on 16:58)

https://katadata.co.id/berita/2020/04/07/dampak-corona-di-ri-1266-hotel-ditutup-

150-ribu-pekerja-dirumahkan (Accessed June 22, 2020 on 17:11)

https://id.wikipedia.org/wiki/Pandemi_koronavirus_di_Indonesia (Accessed June 02, 2020 on $21: 39$ ) 